\title{
THE MILLEDOLER FUNERAL
}

\author{
By Philip M. Brett
}

Probably only a very few persons who use the Library have noticed the picture of the Milledoler Funeral, but those few who have found it, hanging outside Mr. Osborn's office, have paused many times to meditate this curious reminder of the conventions of the mid-nineteenth century. Its history would have been quite forgotten had not the Rev. Dr. Cornelius Brett, when an old man, remembered the scene and written an account of it for posterity to read. Dr. Brett's son, Mr. Philip M. Brett, of the Class of 1892, a Trustee of Rutgers, retells the story.

HaNGIng in the walls of the University Library there is a painting H which has always aroused curiosity. It is a water color depicting a funeral ceremony in a crowded church, draped in black, with two coffins in front of the pulpit. Over the pulpit hangs the coat of arms of the Reformed Dutch Church of America.

For many years the existence of this picture was unknown. Dr. W. H. S. Demarest, while President of Rutgers, discovered it tucked away in a neglected corner of Old Queens. After the picture was cleaned, a silver plate appeared on the frame bearing the inscription:

"Funeral Ceremony

Reverend Philip Milledoler, D.D., LL.D., late

President of Rutgers College, and his wife,

Margaret S. Milledoler, September 26, 1852,

North Reformed Protst. Dutch Church, New York."

No one knows the history of the picture; by whom it was painted or by whose order it was so carefully framed and marked, no one living is now able to tell.

During the Centennial of Old Queens, this picture was hung on the walls of the Chapel as part of an exhibit of interesting prints and documents relating to Rutgers. It was there seen by my father, the Rev. Dr. Cornelius Brett, a great grandson of Dr. Philip Milledoler, who was probably the only person then living who had attended the funeral ceremony. He prepared and has left us his memory of the services and an explanatory description of the picture:

Of the throng gathered in the Church, few survivors remain. The picture seems to be a water color sketch; it must have been prepared by an artist of remarkable skill. 
There were no photographs made at that time and the whole sketch must have been made by the pencil and brush. The dignified architecture of the Church with its Corinthian pillars is delineated with perfect lines, and the miniature portraits of the officiating clergy are recognizable. The arrangement of the congregation must have been made partly from memory and partly from general knowledge of the costume of the day.

As the artistic composition contains so many figures, it is a remarkable picture. The only possible persons or organizations who would have been likely to give an order for such a picture are the Collegiate Consistory of New York City, the family of Dr. Milledoler, or the Trustees of Rutgers College. If it had been ordered by the Church, it would have remained in New York and hung among the portraits of former pastors. If the family had ordered it, it would have remained in one of their homes. I do not know that the Minute Books of the Trustees contain any reference to the picture.

The Rev. Dr. Philip Milledoler, and his second wife, Margaret Steele, died at the home of their daughter, Mrs. James W. Beekman, on Staten Island, in the latter part of the month of September, 1852. The hours of their death were separated by two days and funeral services for both were held in the North Dutch Reformed Church, which stood on Fulton Street, New York, September 26, 1852. This Church has long since been destroyed to make room for the business of lower New York. It was erected previous to the Revolutionary War, and on the capture of New York by British Troops, was used either as a stable or hospital. Services were suspended during the whole of the war, while the ministers fled from the city. After the war it was restored and services renewed. The first English services were held in this building. The beautiful Corinthian columns which supported both galleries and roof were donated by the leading families of New York, including the Schuylers and Roosevelts and the initials of the donors' names were carved at the top of each pillar.

I was present at these ceremonies, and I am shown in the painting beside my father, the Rev. Philip Milledoler Brett, D.D., who graduated from Rutgers in 1834; he was the grandson of Dr. Milledoler. I remember distinctly wearing a mourning band on my hat in memory of my great-grandfather. The details of the service are not remembered, save that the long ride to Greenwood Cemetery ended at the vault which in later years became familiar to me by frequent visits on similar occasions.

Dr. Milledoler had, in earlier years, before he became President of Rutgers College, been one of the Ministers of the Collegiate Church of New York and in recognition of this fact, the Consistory had ordered the pulpit to be appropriately draped in mourning emblems. The pallbearers, seated in the front seat, were leading ministers of New York City. They, as well as the officiating clergy, wear the funeral scarf, which in the early days of my own ministry, was still worn at funeral services. In the pew on the right of the pulpit, the members of the Consistory of that date, are seated. I do not think that any of their faces are intended to be portraits. The officiating clergy in the pulpit are ministers of the Church at that time. I knew them all and recognize their faces. The Rev. Thomas DeWitt, D.D. is speaking. On his left is the Senior Pastor of that time, Rev. Dr. Knox. The Rev. Thomas Vermilyea is seated on the right of Mr. 
DeWitt, and on the extreme right is the Rev. Talbot W. Chambers, D.D., the youngest pastor.

The pathetic feature of the picture is the arrangement of the two caskets, side by side, in front of the pulpit. It is to be noted that the artist has shown the line of division between the family in black, and the rest of the congregation in garments of various colors. He has well shown the bonnets of the day. Naturally, as the picture is taken from the front of the Church, we are looking only at the backs of the people, except those seated in the gallery and the side pews.

Cornelius Brett.

Dr. Philip Milledoler was born in New York City on September 2, 1775. The family moved to Rhinebeck after the British occupation of New York and lived in the house formerly occupied by General Armstrong of the Continental Army. He prepared for college at a private school in Boston and also under instruction from James Hardie, eminent classical scholar, and entered Kings College, now Columbia, in 1789. He graduated in May, 1793, receiving the degree of A.B., and delivered an oration on natural philosophy. He was ordained as a clergyman on May 1, 1794. After serving in various churches in New York and Philadelphia, Dr. Milledoler became President of Rutgers in 1825, continuing in that office until 1840.

During his administration Col. Henry Rutgers, a friend of Dr. Milledoler, presented to the College the bell now hanging in Old Queens, and, after the college had been renamed Rutgers, he added a gift of money. After giving up the Presidency at Rutgers, Dr. Milledoler and his wife lived with their son-in-law, Hon. James W. Beekman of New York, at whose home he died. 